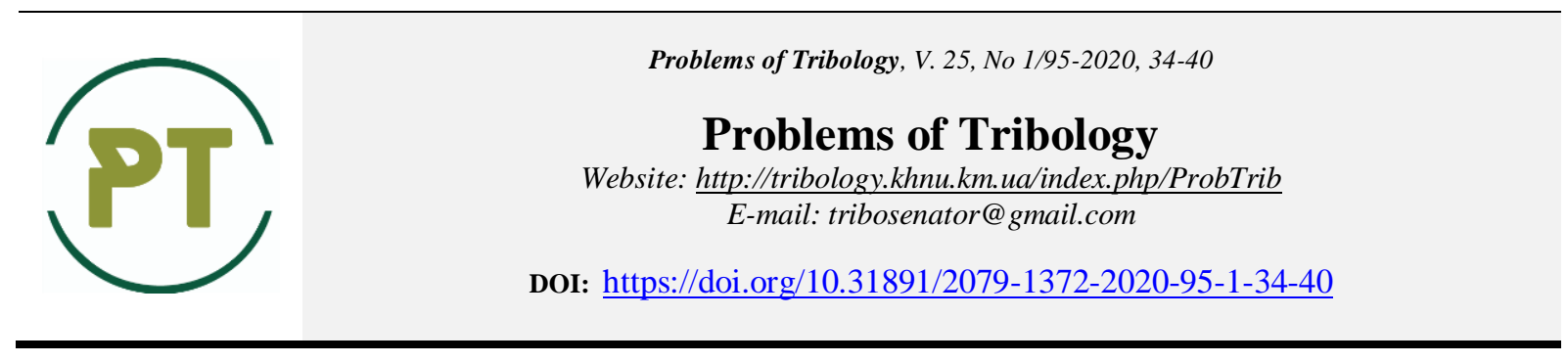

\title{
The study of surface roughness in the process of finishing anti-friction non-abrasive treatment
}

\author{
I. Shepelenko* \\ Central Ukrainian National Technical University, Kropyvnytskyi, Ukraine \\ *E-mail: kntucpfzk@gmail.com
}

\begin{abstract}
An analysis of the literature on the formation of an antifriction coating by finishing anti-friction nonabrasive treatment showed that surface roughness can be the main criterion for assessing the quality of the applied skin. In this regard, the main regularities of changes in the roughness of the surface layer treated with FANT have been established in the work.

The surface treated with the friction-mechanical method FANT was studied on special samples of gray cast iron SCh20 made in the form of disks, and brass L63 was used as the material of the antifriction coating. Since the microrelief of the initial surface significantly affects the continuity of the antifriction coating, the surface roughness was determined before and after coating by the friction-mechanical FANT method taking into account the processing regimes. Studies have shown that the application of anti-friction coatings FANT can improve the quality of the surface, significantly reducing its roughness due to the mashing of brass in the cavities of the surface roughness, as well as partial crushing and smoothing of microroughness combs. The results obtained make it possible to predict and control when applying FANT antifriction coatings such an important geometric parameter of the surface layer as roughness, which largely determines the quality of the processed surface.
\end{abstract}

Key words: roughness, finishing anti-friction non-abrasive treatment (FANT), anti-friction coating, microrelief, processing modes, coating quality

\section{Introduction}

Current trends in the production and operation of machines and mechanisms are aimed at a significant improvement in their operational properties by improving the quality of the working surfaces of parts, the main indicators of which include physical and mechanical properties and geometric characteristics of the surface layer. Surface quality characteristics that determine its operational properties are formed throughout the entire process, however, finishing operations have the greatest impact [1].

The quality of the surface layer is achieved at the stage of manufacturing blanks, their further processing and depends, first of all, on the technological method of surface treatment, which ensures optimal roughness in the contact zone and the necessary physical and mechanical properties of the work surfaces of the part.

The generally recognized direction in improving the quality of the working surfaces of machine parts is the development and widespread use of coatings, including antifriction [2]. Out of the whole variety of methods for producing antifriction coatings, coatings with optimal values of hardness and elastic modulus with enhanced antifriction properties, which provide favorable internal stresses, as well as maximum adhesive characteristics of the coating with the base material, are preferable [3]. Thus, an important reserve for improving the quality of parts during their manufacture and repair is the application of antifriction coatings in finishing operations.

All of the above requirements are met by the group of technologies for finishing anti-friction nonabrasive treatment (FANT), which is realized due to the frictional interaction of a copper-containing tool with the surface of the workpiece. Rubbing the friction surface with a tool made of copper and its alloys in the presence of a process fluid allows you to create coatings $2-5 \mu \mathrm{m}$ thick on the friction surface [4], as well as harden the surface of the base material to a depth of $70-80 \mu \mathrm{m}$ due to high pressure at the point of linear contact [5]. However, the wider application of FANT is constrained by the lack of extensive information on the relationship 
of technological factors of the process with the geometric parameters of the surface layer, and above all, with the roughness, which, according to some researchers $[6,7]$, is the main quality criterion for the obtained FANT coating.

\section{Literature Review}

It has been established [8] that the increase in wear resistance, contact strength, corrosion resistance and other operational properties of parts is associated with controlling the state parameters of the surface layer and, above all, the surface roughness. The parameters and characteristics of surface roughness are regulated by GOST

2789-73: three high-altitude - $R_{a}, R_{z}, R_{\max }$, two step-wise - $S_{m}, S$ and the parameter of the relative reference profile length $-t_{p}[9]$.

The data presented in $[8,10$ - 14, etc.] indicate a significant effect of various parameters of micro and macrogeometry on the operational characteristics of work surfaces.

In [10], it has been indicated that surface roughness is one of the main factors determining the wear rate of friction pairs. Moreover, the influence of the initial roughness on wear manifests itself during the running-in period, and the shape and height of microroughness affect the wear of the mating surfaces. The wear rate is largely dependent on the magnitude of the contact and the stress state of the surface layer, which are also associated with the size and shape of the microroughness [8].

The surface roughness parameters in a certain way affect the indicators of its physical state (hardening, internal stresses, microcracks, structure) [11].

Roughness elements are stress concentrators, reducing the strength characteristics of the material. The value of stress concentration depends on the depth of the microroughness troughs and their rounding radius [12].

A significant effect of roughness on corrosion resistance has been proven [13]. The latter increases with a decrease in altitude parameters, since substances that form foci of corrosion and intensify the process of metal destruction are collected in the cavities. Low roughness also allows for better retention of the passivating film, which protects the surface from external influences. However, it is advisable to reduce the surface roughness to a certain value, since low roughness leads to increased wear due to setting of mating surfaces.

The reliability of fixed joints of parts also largely depends on the surface roughness [14]. At high $R_{a}$ values, due to crushing of microprotrusions, the fit is impaired, and the mating life is reduced. At low $R_{a}$ values, the necessary adhesion of the mating surfaces is not ensured. For each part and its inherent conditions of friction, there is a certain optimal contour contact area, which is a set of contact spots that are optimally located on the nominal area. Moreover, the roughness of the friction surfaces also has optimal values, which are found experimentally for specific friction pairs.

Thus, the choice of roughness parameters is carried out taking into account the operating conditions of the parts. An initial roughness close to experimental reduces wear, temperature and coefficient of friction. The resulting equilibrium roughness makes it possible to minimize the amount of wear and the duration of the running-in of the friction surfaces.

Surface quality parameters that determine its operational properties are formed throughout the entire technological process, however, finishing operations have the greatest impact, the study of which has always been given great attention [15]. Therefore, it is the finishing process that is entrusted with the task of ensuring the required quality of the surface layer, which can be achieved by coating. In our opinion, the application of antifriction coatings at the final stages of the technological process by the FANT method will ensure optimal roughness in the contact zone and the necessary physical and mechanical properties of the work surfaces of the part.

In a number of studies on the formation of the anti-friction coating FANT, it has been found that surface roughness is the main criterion for assessing the quality of the applied skin. Due to the fact that the authors of [16] have obtained and justified the initial surface microrelief to create favorable conditions for micro cutting of antifriction material by microprotrusions of the initial surface and to improve the quality of coating formation by the friction-mechanical method, there is a need to conduct special studies of the influence of FANT at specified parameters on roughness surface layer.

\section{Purpose}

The aim of the work is to establish the basic laws of changing the roughness of the surface layer treated with FANT.

\section{Research Methodology}

The study of the surface treated by the friction-mechanical method of FANT was carried out on special samples of gray cast iron SCh20 made in the form of disks. Moreover, to intensify micro-cutting of antifriction material during coating, a certain microrelief had been previously created on the surface of the disk, according to the recommendations of $[16,17]$, using turning cutters made of VK4 hard alloy. 
Since the shape and dimensions of the microroughnesses of the treated surface are determined, first of all, by the geometry of the cutter in terms of plan and the size of its feed, to obtain different protrusions and cavities of microroughnesses on the surface of the research samples, we have selected certain values of the main $\varphi$ and auxiliary $\varphi_{1}$ angles in the plan [16] and the values of the transverse feed $S$ of the cutter, which provided a step of protrusions of the microrelief of $0.05 ; 0.10 ; 0.15 ; 0.175 \mathrm{~mm}$. The pressing force of the anti-friction bar to the treated surface $P$ was $82.4 \mathrm{~N} ; 164.6 \mathrm{~N}$, which corresponds at a nominal contact area $a \times b=18 \mathrm{~mm}^{2}$ to contact pressure $q-4.6 \mathrm{MPa}, 9.2 \mathrm{MPa}$.

Assessment of the quality of the coating was carried out after two, six and twelve passes of the antifriction bar along the treated surface.

Coating by the friction-mechanical method FANT was carried out according to the method developed by the authors and using the device [17] on a vertically milling machine. As an antifriction coating material, L63 brass was used.

Thus, on SCh20 cast iron research samples (Fig. 1), an antifriction coating was applied in the form of a track across the microprotrusions of the base. The width of the applied coating corresponded to the width of the antifriction tool $-6 \mathrm{~mm}$.

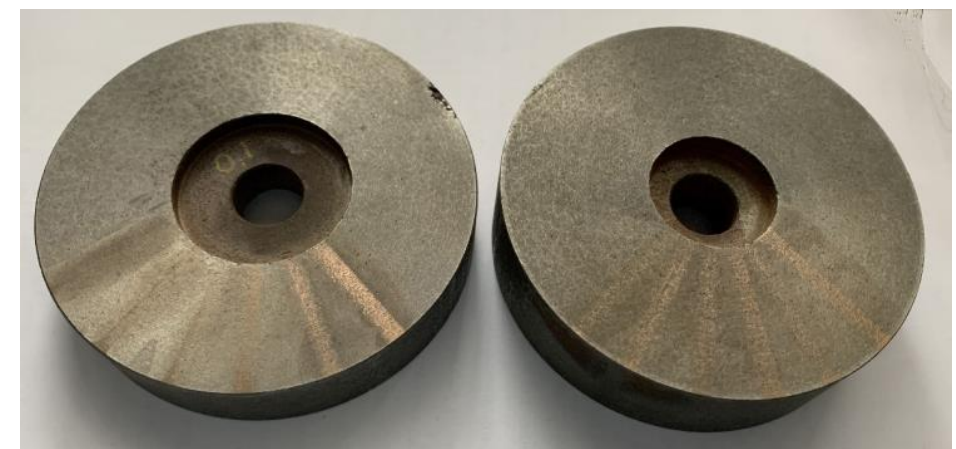

Fig. 1. Samples from cast iron SCh20 processed by the friction-mechanical method FANT

The study of roughness parameters before and after FANT was carried out on a Mahr XR20 profilograph, a PC-based device. The surface roughness was estimated by the arithmetic mean deviation of the profile $R_{a}$. As the value of the roughness parameter $R_{a}$, we took the average value obtained as a result of three measurements. The continuity of the coating was determined based on the results of metallographic analysis of the surface, using methods of digital image processing on a PC.

\section{Results}

Considering that the surface roughness obtained by FANT, along with the continuity of the coating, can be the main criteria for the quality of the applied coating, which largely determines the running-in process during the initial period of operation, the main attention was paid to the study of this particular geometric parameter of the microrelief.

Technological factors for the selected FANT scheme include: an effort of pressing the anti-friction bar $P$, the number of rubbing cycles (passes) $N$ and the tool speed $V$. Due to the low $V$ values, the influence of this factor was not taken into account in the studies.

Since the microrelief of the initial surface significantly affects the continuity of the antifriction coating, the surface roughness was determined in the work before and after coating by the friction-mechanical method FANT.

The change in the values of the arithmetic mean deviation of the profile of the samples was determined as:

$$
\Delta R_{a}=R_{a F A N T}-R_{a}
$$

where $R_{a F A N T}$ - surface roughness after FANT, $\mu \mathrm{m}$;

$R_{a}$-initial roughness, $\mu \mathrm{m}$.

The obtained values made it possible to establish the basic laws of changing values $\frac{R_{a F A N T}}{R_{a}}$ from the technological parameters of FANT (Fig. 2 - 4). 


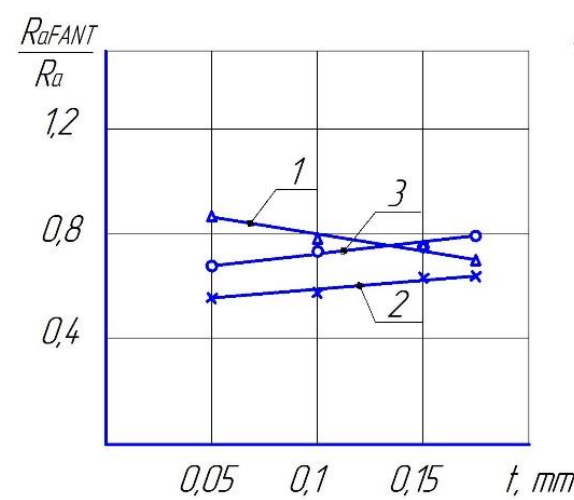

a

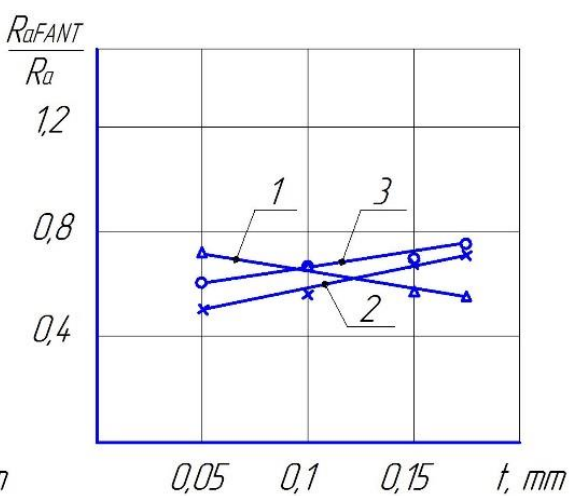

b

Fig. 2. Dependence of ratio $R_{a F A N T} / R_{a}$ during the FANT process on the step of protrusions of the microrelief of the initial surface $t$ with the effort of $P=82.4 \mathrm{~N}$ (a),

$P=164.6 \mathrm{~N}$ (b) and the number of rubbing cycles:

$$
\begin{aligned}
& \text { 1-2; } \\
& 2-6 ; \\
& 3-12
\end{aligned}
$$

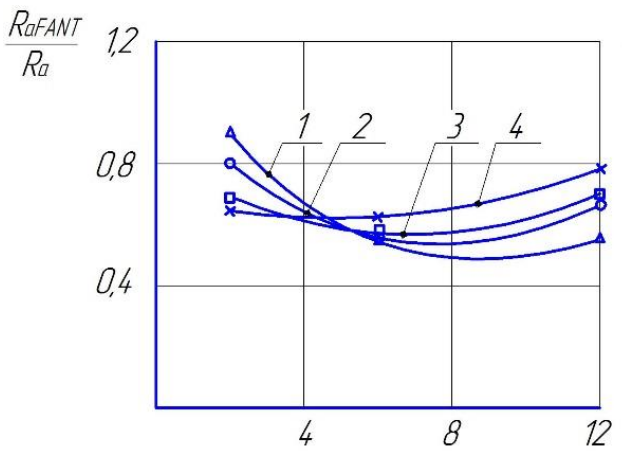

a

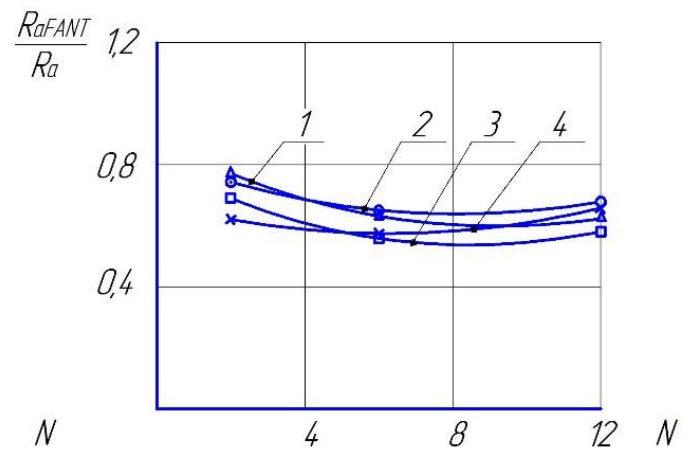

b

Fig. 3. Dependence of ratio $R_{a F A N T} / R_{a}$ during the FANT process on the number of rubbing cycles $N$ with the effort of $P=82.4 \mathrm{~N}$ (a), $P=164.6 \mathrm{~N}$ (b) and the pitch of the microrelief protrusions of the initial surface:

$$
\begin{gathered}
\text { 1 - 0.05 mm; } \\
\text { 2-0.1 mm; } \\
3 \text { - } 0.15 \mathrm{~mm} ; \\
4 \text { - } 0.175 \mathrm{~mm}
\end{gathered}
$$

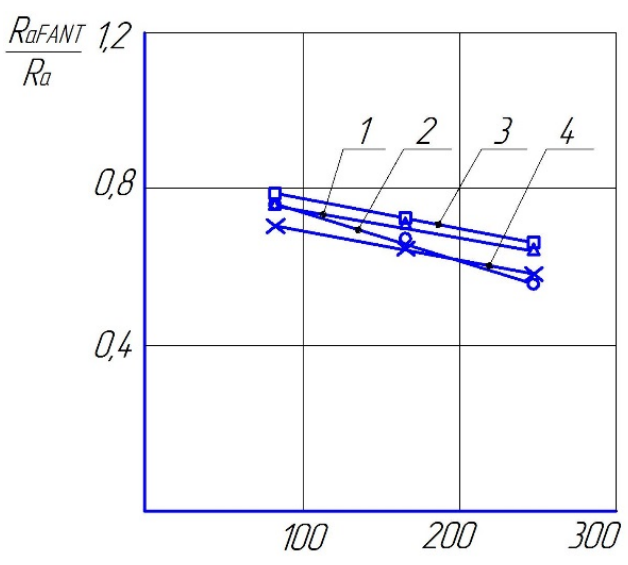

a

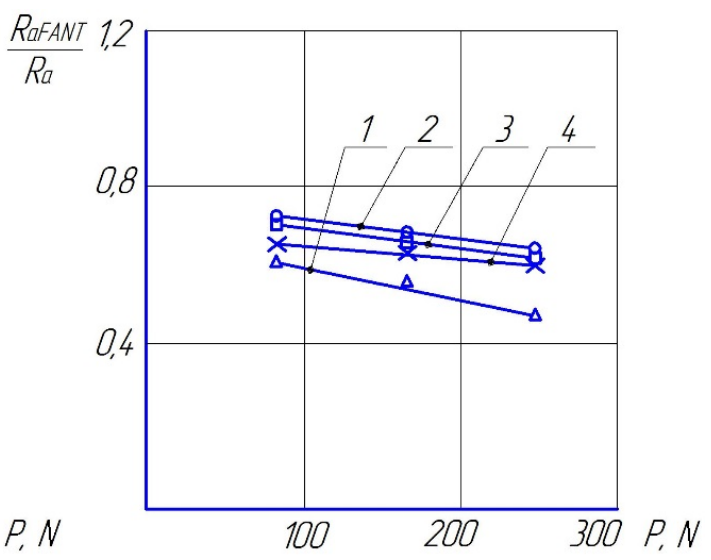

b

Fig. 4. Dependence of the ratio $R_{a F A N T} / R_{a}$ during the FANT process on the effort $P$ with the number of rubbing cycles $N=2$ (a), $N=6$ (b) and the pitch of the microrelief protrusions of the initial surface:

$$
\begin{gathered}
1 \text { - } 0.05 \mathrm{~mm} ; \\
\text { 2-0.1 mm; } \\
3-0.15 \mathrm{~mm} ; \\
4-0.175 \mathrm{~mm}
\end{gathered}
$$


Fig. 5.

Profilograms of the surface of the studied samples after turning and subsequent FANT are presented in

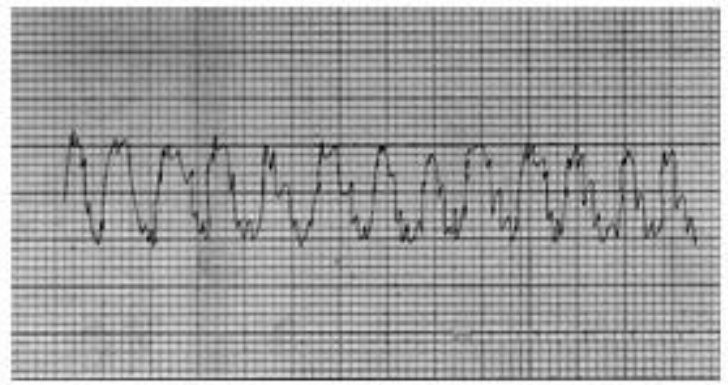

a

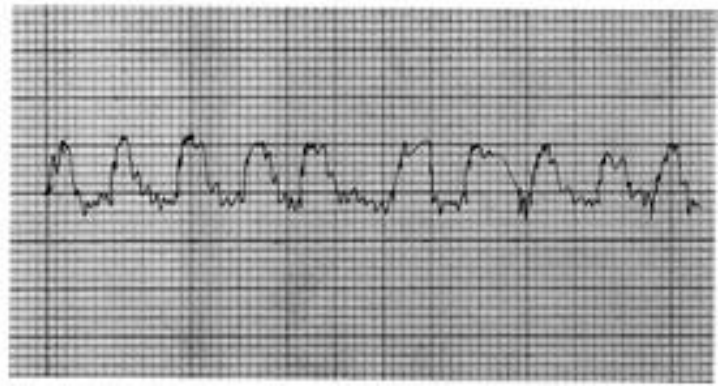

b

Fig. 5 - Profilograms of measuring the roughness of the samples after turning (a) and subsequent FABO (b) $($ vertical magnification $\times \mathbf{5 0 0}$, horizontal $\times \mathbf{5 0}$ )

An analysis of the experimental data (Fig. 2 - 5) convincingly indicates a significant change in the arithmetic mean deviation of the $\Delta R_{a}$ profile of the treated surface after FANT. At the same time, the mechanism of these changes for different values of the roughness of the initial surface and processing conditions for the selected scheme is different.

The more significant the value of $\frac{R_{a F A N T}}{R_{a}}$ is, the higher is the Ra value of the initial surface. In this sense, the highest value of $\frac{R_{a F A N T}}{R_{a}}$ is observed when applying coatings to a previously prepared surface for the coating with a step of $0.175 \mathrm{~mm}$ (Fig. 2). This confirms the fact of the special importance of the role of microcutting in the formation of an antifriction coating [18], as well as the effect of rubbing material as a smoothing tool.

However, high $R_{a}$ values of the initial surface do not allow to obtain a continuous coating, which makes it possible to destroy it due to the contact interaction of the contacting surfaces. When applying the coating by the friction-mechanical method FANT on a pre-treated surface with a feed of $0.1 \mathrm{~mm} / \mathrm{rev}$, it was possible to obtain a continuous coating.

It was established (Fig. 3 ) that the most rational number of rubbing cycles (passes) is $2 \div 6$. Subsequent rubbing cycles do not increase the quality of the antifriction coating.

With an increase in the pressing effort (contact pressure) of the antifriction tool to the surface being machined (Fig. 4), a decrease in roughness is observed, which is explained by a more intense mashing of the antifriction material (L63 brass) into the cavities of the microprotrusions and smoothing of their vertices. This is also confirmed by the data of profilograms (Fig. 5), which indicate that the application of antifriction coatings FANT improves the quality of the surface, smoothing microprotrusions and cavities by applying antifriction material to their surface.

\section{Summary}

Studies of the influence of the FANT modes, as well as the state of the initial surface on the roughness of the treated surface, allowed us to make the following conclusions:

- with increasing parameter of the initial surface roughness $\mathrm{Ra}$, the magnitude of the change in the arithmetic mean deviation of the profile $\Delta R_{a}$ also increases;

- high initial values of the arithmetic mean deviation of the profile $R_{a}(12.0 \div 5 \mu \mathrm{m})$ do not allow to obtain a continuous, and therefore, high-quality antifriction FANT coating. This is because on the surface having rough machining, it is impossible to create the necessary specific pressure between brass and cast iron, which means that there are no conditions for widespread setting. To obtain a high-quality coating, it is necessary to have the initial roughness of the treated surface not lower than $R_{a}=2.5 \mu \mathrm{m}$;

- obtaining a high-quality anti-friction coating with the selected FANT scheme became possible with the following processing modes: anti-friction bar pressing effort $P=164.6 \mathrm{~N}$, number of rubbing cycles $N=2$; 
- FANT anti-friction coatings can improve the quality of the surface, significantly reducing its roughness due to mashing of brass into the cavities of the surface roughness, as well as partial crumpling and smoothing of microroughness combs. This leads to a more uniform and denser coating on the treated surface;

- the results of the studies allow us to predict and control while applying anti-friction FANT coatings such an important geometric parameter of the surface layer as roughness, which largely determines the quality of the treated surface.

\section{References}

1. Ryzhov, E.V., Klimenko, S.A., Gutsalenko, O.G. Technological support for the quality of coated parts. Kiev, Ukraine: Naukova Dumka, 1994, p. 181. [Russian]

2. Lyashenko, B.A., Solovyh, E.K., Mirnenko, V.I. et al. Optimization of coating technology according to the criteria of strength and wear resistance. Kiev, Ukraine: NAS of Ukraine, IPP named after Pisarenko G.S., 2010, p. 193. [Russian]

3. Chernovol, M.I., Shepelenko, I.V. Methods of forming antifriction coatings on metal friction surfaces. Collection of scientific papers of Kirovograd National Technical University "Engineering in agricultural production, industry engineering, automation”, 2012, Issue 25 (1), pp. 3-8. [Russian]

4. Ragutkin, A.V., Sidorov, M.I., Stavrovskij, M.E. Some Aspects of Antifriction Coatings Application Efficiency by Means of Finishing Nonabrasive Antifriction Treatment. Journal of Mining Institute 236, pp. 239-244. [English]

5. Balabanov, V.I., Bolgov, V.Ju., Ishhenko, S.A. Friction application of nanoscale antifriction coatings on parts. Nanotechnology, ecology, production 1(3), pp. 104-107. [Russian]

6. Pogonyshev, V.A., Panov, M.V. Theoretical and experimental basis for increasing the wear resistance of machine parts. Mechanics and physics of processes on the surface and in contact of solids, parts of technological and energy equipment 4, pp. 78-84 (2011). [Russian]

7. Bersudskij, A.L.: The mechanism of formation of antifriction coatings during hardening treatment. VESTNIK of Samara University. Aerospace and Mechanical Engineering 2(10), pp. 81-84. [Russian]

8. Sulima, A.M., Shulov, V.A., Yagodkin, Yu.D. Surface layer and performance of machine parts. Moscow, Russia: Mechanical Engineering, 1988, p. 240. [Russian]

9. GOST 2789-73 (ST SEV 638-77). Surface roughness. Moscow, Russia: USSR State Committee for Standards, 1981. [Russian]

10. Prikhodko, V.M., Medelyaev, I.A., Fatyukhin, D.S. Formation of operational properties of machine parts by ultrasonic methods: monograph. Moscow, Russia: MADI, 2015, p. 264. [Russian]

11. Nazarov, Yu.F., Shkilko, A.M., Tikhonenko, V.V., Kompaneyets, I.V. Methods of research and control of surface roughness of metals and alloys. Physical surface engineering, 2007, Vol. 5, No. 3-4, pp. $207-$ 216. [Russian]

12. Zlenko, M.A., Nagaytsev, M.V., Dovbysh, V.M. Additive technologies in mechanical engineering. Moscow, Russia: NAMI, 2015, p. 220. [Russian]

13. Akulovich, L.M., Sergeev, L.E. et al. Corrosion resistance of alloy steel parts after magnetic abrasive treatment. Bulletin of Polotsk State University. Series B, Industry. Applied Science, 2018, No. 11, pp. 4550. [Russian]

14. Kuzmenko, I.V. Restoration and hardening of rolling bearing housings by friction rubbing with copper. PhD thesis. Moscow, 2000. [Russian]

15. Chernovol, M.I., Shepelenko, I.V., Budar Mohamed, R.F. Improving the quality of finishing processing of holes. Collection of scientific papers of Kirovograd National Technical University "Engineering in agricultural production, industry engineering, automation", 2016, Vol. 29, pp. 104-111. [Russian]

16. Shepelenko, I.V., Tsekhanov, Yu.O., Nemyrovskyi, Ya.B., Posvyatenko, E.K., Eremin, P.M. Investigation of micro-cutting in the process of finishing antifriction non-abrasive treatment. Proceedings of the IX International Scientific and Technical Conference "Progressive Technologies in Mechanical Engineering", 2020, pp. 162-164. [Ukrainian]

17. I. Shepelenko, Y. Nemyrovskyi, Y. Tsekhanov, E. Posviatenko, E. Modeling of contact interaction of micro roughness at FANT. In: I-th International scientific and technical conference «Prospects for the development of mechanical engineering and transport-2019», pp. 218-219. [Russian]

18. Shepelenko, I.V., Posviatenko, E.K., Cherkun, V.V. The mechanism of formation of anti-friction coatings by employing friction-mechanical method. Problems of Tribology, 2019, №1, pp. 35-39 [English]. 
Шепеленко І.В. Дослідження шорсткості поверхні в процесі фінішної антифрикційної безабразивної обробки

Виконаний аналіз літературних джерел, присвячений утворенню антифрикційного покриття фінішною антифрикційною безабразивною обробкою (ФАБО) показав, що шорсткість поверхні може бути основним критерієм оцінки якості плівки, що наноситься. У зв'язку з цим у роботі встановлені основні закономірності зміни шорсткості поверхневого шару, обробленого ФАБО.

Дослідження поверхні, обробленої фрикційно-механічним методом ФАБО, здійснювалося на спеціальних зразках із сірого чавуну СЧ 20 , які були виготовлені у вигляді дисків, а в якості матеріалу антифрикційного покриття вибрана латунь Л63. Оскільки на суцільність антифрикційного покриття суттєво впливає мікрорельєф вихідної поверхні, в роботі визначалася шорсткість поверхні до і після нанесення покриттів фрикційно-механічним методом ФАБО з урахуванням режимів обробки. Шорсткість поверхні оцінювалася середнім арифметичним відхиленням профілю $R_{a}$. За величину параметра шорсткості $R_{a}$ брали середнє значення, отримане в результаті трьох вимірів. Суцільність покриття визначилась, виходячи з результатів металографічного аналізу поверхні, використовуючи методи цифрової обробки зображень на ПК.

Встановлено, що високі значення $R_{a}$ вихідної поверхні не дають можливості отримувати якісне покриття, що може призвести його руйнування внаслідок контактної взаємодії контактуючих поверхонь. Для отримання суцільного покриття ФАБО необхідно, щоб вихідна шорсткість оброблюваної поверхні була не нижче $R_{a}=2,5$ мкм. Зі збільшенням контактного тиску антифрикційного інструмента до оброблюваної поверхні спостерігається зниження шорсткості, що пояснюється більш інтенсивним затиранням антифрикційного матеріалу (латуні Л63) в западини мікровиступів і згладжуванням їх вершин.

Проведені дослідження показали, що нанесення антифрикційного покриття ФАБО дає змогу підвищувати якість поверхні, значно знижуючи її шорсткість за рахунок затирання латуні в западини шорсткості поверхні, а також часткового зминання і згладжування гребінців мікронерівностей. Отримані результати дають підстави прогнозувати та керувати при нанесенні антифрикційних покриттів ФАБО таким важливим геометричним параметром поверхневого шару, як шорсткість, який багато в чому визначає якість обробленої поверхні.

Ключові слова: шорсткість, фінішна антифрикційна безабразивна обробка (ФАБО), антифрикційне покриття, мікрорельєф, режими обробки, якість покриття. 